Dealing with the transitions from water to ice, and from water-vapour to ice, two papers were read by Dr. B. J. Mason, representing the work of the Imperial College group. In the first Dr. Mason gave a full acount of the extremely beautiful method which he has developed for growing smell crystals of ice at controlled temperatures and water-vapour concentrations in a thermal-gradient air box. He has shown that temperature alone determines the particular habit adopted by ice crystals, except at high supersaturation when dendritic growth occurs. In the temperature ranges from $0^{\circ}$ to $-3^{\circ} \mathrm{C}$., from $-8^{\circ}$ to $-12^{\circ} \mathrm{C}$. and from $-16^{\circ}$ to $-25^{\circ} \mathrm{C}$., hexagonal plates are the rule. On the other hand, from $-3^{\circ}$ to $-8^{\circ} \mathrm{C}$., and below $-25^{\circ} \mathrm{C}$., the predominant form is either the elongated hexagonal prism or the hollow prism which sometimes has a spiral structure. The fern-like dendritic crystals occur only between $-12^{\circ}$ and $-16^{\circ} \mathrm{C}$. By growing crystals successively at different temperatures Dr. Mason has succeeded in producing combined forms which reproduce many of the beautiful effects long known in snowlekes, which may be interpreted as indicating the various temperature regimes through which the snowflakes moved during their formation. These observations are of fundamental meteorological importance and also of great physical interest, because until now very little work has been done on the influence of temperature on crystal-form, and it would appear that the sharp changes of habit with temperature indicate that we are dealing here with a thermodynamic phenomenon depending on the relative values of the free energy of growth in different habits, as Prof. J. D. Bernal suggested at the meeting.

Dr. Mason's other peper described a series of carefully controlled experiments, on the supercooling and freezing of water drops. He showed two curves relating the volumes of drops to the temperatures at which they froze- one for freezing induced by nuclei, and another for the case in which nuclei are absent. In the latter case supercooling for drops as small as $l \mu$ in diameter can be effected down to $-41^{\circ}$ C. and for $1-\mathrm{mm}$. drops down to $-3^{\circ} \mathrm{C}$. Crystallization at these temperatures is an almost explosive process, resulting in the fracture of the frozen droplet and its shattering, a phenomenon which may be of great importance for the rapid spread of nucleation through super-cooled clouds in the atmosphere.

Dr. M. Blackman (Imperial College, London) reported a study by electron diffraction of epitaxial growth of ice on silver iodide crystals. Silver iodide is the only substance at present known to be capable of producing rapid nucleation of ice. By controlled growth of single crystals of ice, Dr. Blackman has been able to show the crystal formation of the ice with sufficient penetration to bring out the underlying silver iodide lattice.
J. D. Bernal

\title{
MIDDLE EAST TECHNICAL UNIVERSITY, ANKARA
}

\section{BY DR. TURGUT YAZICIOGLU}

$\mathrm{T}$ HE foundation stone of the Middle East Technical University in Ankara was laid on October 3, 1957, in the presence of the President of the Turkish Republic, the Prime Minister, the Minister of Education, the heads of the foreign aid committees, the Ambessedors of Great Britain and of the United States of America and other distinguished guests.

The University has, in fact, been working tem. porarily in a building in Ankara for two years. In 1956 there were 175 students attending the Colleges of Architecture and Administration, and in February 1957 the College of Engineering was established, followed in September by the creation of a research department for nuclear physics.

Foundations for colleges of mining, geology, agriculture and forestry were laid in 1956, and in 1958 students of electrical engineering, mining and geology will be admitted.

There are at present five foreign professors at the University, but arrangements have been made for further staff to be recruited through the United Nations (including two professors of architecture and one of administration), through Unesco (including professors of construction engineering, and of machinery), and through the technical aid programme of the British Government (professors of physics and of electrical engineering).

Thus by this year there will be altogether twelve foreign professors on the University staff; the Turkish teaching staff will number thirty.

The site designated for the construction of the Middle East Technical University is about three miles from Ankara and covers an area of about
4,500 hectares ( 11,115 acres). The University campus will comprise, besides the college buildings, dormitories, faculty bousing, libraries, a theatre, sports grounds, restaurants and other accommodation. All the plans and projects have been drawn up by the Turkish Ministry of Works in co-operation with the University of Pennsylvania.

According to the first ten-year programme, the University will have about 6,000 students, 2,500 teaching and research staff, and forty departments (including teaching and research units) at the end of the first decade.

During this ten-year period the Turkish Government is to make grants to the University totalling 265 million Turkish lira (about $£ 33$ million), of which almost half will be invested, while over the same period foreign aid will be available to a total of 26.5 million dollars. In addition, the British Ambassador, in his speech during the inaugural ceremony, promised a further sum of $£ 25,000$ from the British Government in the present year.

The University is designed to fulfil the need for an international centre of higher learning to serve the requirements of the developing Middle East. It is founded on the belief that the development of the region in a manner satisfying the demands of a progressive society requires the integration of techniques with human needs and aspirations. The University considers its major responsibility to be the training of a growing number of educated men and women, able to work creatively on the problems of the Middle East, using the most advanced techniques of our era. 


\section{History of the University}

Constituted as a university only since January 13, 1957, the Middle East Technical University now has two faculties. From the single group of fifty students, with which the teaching programme opened in November 1956, the Government of Turkey plans that the University shall grow to major size, involving six faculties, with a complete research establishment matching the academic activities of each department with a programme of applied research and development work in industrial and agricultural problems. The University's teaching programme, conducted in English, with its emphasis on unity of thought and action, and on the correlation of teaching and research, should make it an institution unique in the Middle East.

The first step in the establishment of the University was taken in 1953, when a survey of building and planning legislation revealed the need for universitytrained technical people in the professions. As a result of this survey, a school of architecture and town-planning was suggested, to be integrated with research institutes in building and planning. A complete programme for the school was prepared by a United Nations Mission, under the direction of Dr. G. Holmes Perkins, dean of the University of Pennsylvania School of Fine Arts.

The Perkins Committee received not only the enthusiastic and energetic support of the President of Turkey, the President of the Grand National Assembly and the Prime Minister, but also the effective co-operation of a committee for the school, headed by the Minister of Education, and having as members Mr. Vecdi Diker, Mr. Ahmed Tokus, Mr. Mihat Yenen and Mr. Adli Yener.

Following the Perkins Committee recommendations, a request was submitted to the United Nations for assistance in establishing the first faculty. In the autumn of 1956 the Committee was reactivated by the Minister of Education as an acting Board of Trustees. Under its guidance, the programme of the University has been developed and its teaching opera. tions begun. Fifty students first received instruction in architecture on November 1, 1956, in a rented build. ing at 18 Müdafaa Caddesi, in Ankara. The formal inauguration ceremony was held on November 15.

During the winter, plans were made for expansion of the teaching facilities and the acquisition of a campus. On January 13, 1957, a provisional law authorizing the establishment of the University was passed by the Grand National Assembly. The Minister of Education has set aside a magnificent site for the development of a terching and research centre, and plans for the construction of University facilities are moving ahead at top speed.

Since the beginning of the spring term 1957 the second faculty, that of engineering, has been in operation. Its first Department, of Mechanical Engineering, was joined by a Department of Civil Engineering last autumn. At the same time, the faculty of administration was opened. Continuing to develop in this way, all six faculties with their research institutes will, it is hoped, be in existence within five years, permitting rapid expansion toward the goal set by the Government.

\section{OBITUARY}

\section{Viscount Waverley, G.C.B., O.M., G.C.S.I., G.C.I.E., F.R.S.}

There have been many tributes to the outstanding qualities of mind and character which made John Anderson, the first Viscount Waverley, one of the greatest, beyond all question, of the many great public servants of Great Britain. It may be doubted, however, whether any of the numerous accounts of his remarkable career have yet done full justice to the special nature of the service which he was qualified to render to the nation, especially in two world wars, by his experience as a student of science at Edinburgh and a postgraduate research worker at Leipzig, before he entered the Civil Service. It should be understood that this course of scientific studies and practice in research did not serve him as a mere introduction, or a stepping-stone, to an official and ministerial career of such extraordinary distinction, in which he beceme a permanent UnderSecretary of State (Home Office) by the time that he was forty, governor of Bengal ten years later, and then, as Member of Parliament for the Scottish Universities, Minister for Home Affairs and Home Security, Lord President of the Council and, finally, Chancellor of the Exchequer, during the Second World War. Through it all, and with his imperishable and comprehensive memory as a background, the supreme importance of scientific progress had remained with him a matter of central interest and conviction. It was no mere matter of curious coincidence that the subject for his postgraduate researches and Ph.D. thesis at Leipzig had been the chemistry of uranium, and that nearly forty years later, and behind the densest curtain of war-time secrecy, he had found himself charged with the chief responsibility, on behalf of the War Cabinet, for Britain's part in the development of researches on atomic energy-primarily, of course, for purposes of war, but with an ultimate view, even then, to peaceful applications.

My first encounter with the future Lord Waverley was soon after the outbreak of the First World War, in 1914. Sir Robert Morant, as chairman of the English Health Insurance Commission, had found himself suddenly faced with the abrupt disappearance of all the important drugs which had been obtained from Germany; and he promptly recognized that in John Anderson, a brillient young Civil servant, with the then almost unique qualification of scientific training and experience, he had the man to deal with the position thus created. I had newly joined the scientific staff of the then embryonic Medical Research Committee (now Council), and its first secretary, Walter Fletcher, had asked me to act on its behalf with reference to the same emergency; so that Anderson and I naturally met and kept contact over problems of common interest and responsibility. He also became a member, and a most important one, of a Royal Society Committee, appointed to enlist scientific co-operation to meet sudden needs of the same kind. Thereafter he was swept away to heights of administrative promotion where $I$ lost 